\title{
Nitrogen-fixing, photosynthetic, anaerobic bacteria associated with pelagic copepods
}

\author{
Lita M. Proctor* \\ Department of Oceanography, Florida State University, Tallahassee, Florida 32306-3048, USA
}

\begin{abstract}
Purple sulfur bacteria are photosynthetic, anaerobic microorganisms that fix carbon dioxide using hydrogen sulfide as an electron donor; many are also nitrogen fixers. Because of their requirements for sulfide or organic carbon as electron donors in anoxygenic photosynthesis, these bacteria are generally thought to be limited to shallow, organic-rich, anoxic environments such as subtidal marine sediments. We report here the discovery of nitrogen-fixing, purple sulfur bacteria associated with pelagic copepods from the Caribbean Sea. Anaerobic incubations of bacteria associated with fullgut and voided-gut copepods resulted in enrichments of purple/red-pigmented purple sulfur bacteria while anaerobic incubations of bacteria associated with fecal pellets did not yield any purple sulfur bacteria, suggesting that the photosynthetic anaerobes were specifically associated with copepods. Pigment analysis of the Caribbean Sea copepod-associated bacterial enrichments demonstrated that these bacteria possess bacteriochlorophyll $a$ and carotenoids in the okenone series, confirming that these bacteria are purple sulfur bacteria. Increases in acetylene reduction paralleled the growth of purple sulfur bacteria in the copepod enrichments, suggesting that the purple sulfur bacteria are active nitrogen fixers. The association of these bacteria with planktonic copepods suggests a previously unrecognized role for photosynthetic anaerobes in the marine $\mathrm{S}, \mathrm{N}$ and $\mathrm{C}$ cycles, even in the aerobic water column of the open ocean.
\end{abstract}

KEY WORDS: Marine purple sulfur bacteria Pelagic copepods Gut bacteria Nitrogen fixation

\section{INTRODUCTION}

Purple sulfur bacteria, in the $\gamma$-proteobacteria (Fowler et al. 1984), are a group of photosynthetic anaerobes which fix carbon dioxide without evolving oxygen (Imhoff 1992). Purple sulfur bacteria perform anoxygenic photosynthesis using bacteriochlorophyll as the light-harvesting pigment. These bacteria use reduced compounds other than water as a source of reductant and typically use reduced sulfur compounds or simple organic compounds as the external electron donors in photosynthesis (Pfennig \& Truper 1994).

Bacteriochlorophyll synthesis is inhibited under high light intensity, is maximal under low light intensity and is completely inhibited in the presence of oxygen (Pfennig 1978). Consequently, anoxygenic photosynthesis is possible only under relatively low light and fully anoxic conditions. Furthermore, because of their

\footnotetext{
•E-mail: proctor@ocean.fsu.edu
}

requirement for sulfide, these microorganisms are generally thought to be restricted to organic-rich habitats where sulfate-reducing bacteria can supply sulfide (Pfennig \& Truper 1994). Typical environments in which purple sulfur bacteria are found include marine sediments and mats (Jørgenson \& Fenchel 1974), salt marshes (Paterek \& Paynter 1988) and stratified lakes (Guerrero et al. 1985), where they are found at the oxic/anoxic interface.

Copepods are crustacean marine zooplankton, ranging in size from less than $1 \mathrm{~mm}$ to greater than $10 \mathrm{~mm}$ in length, which dominate the mesozooplankton in the upper $600 \mathrm{~m}$ of the world's oceans (Star \& Mullin 1981). Typical copepod abundances can range from 1 to 100 copepods $\mathrm{m}^{-3}$ (Longhurst 1985), although copepods can be orders of magnitude more dense at fronts, during phytoplankton blooms and at the thermocline (Longhurst \& Herman 1981).

Growing evidence suggests that copepods possess a gut microbial flora (Sochard et al. 1979, Nagasawa \& 
Nemoto 1988, Delille \& Razouls 1994, Hansen \& Bech 1996). Although the members of this microbial flora are not known, the metabolic activities of some of these microbes are apparent in the production of reduced gases such as methane, which have been detected from incubations of copepods (Oremland 1979, de Angelis \& Lee 1994) and their fecal pellets (Bianchi et al. 1992). Sulfide, another anaerobic metabolic byproduct, has also been detected in the ocean (Cutter \& Krahforst 1988). Sites for sulfide production include fecal pellets and marine snow (Shanks \& Reeder 1993); however, no studies have examined copepod-associated bacteria as agents of sulfide cycling in the ocean.

We report here the discovery of purple sulfur bacteria associated with planktonic copepods. We employed several approaches to determine whether purple sulfur bacteria are specifically associated with the copepods. The plankton was collected in an $800 \mathrm{~m}$ water column far from marine sediments or other potential benthic sources for purple sulfur bacteria. Only anoxic incubations of bacteria associated with full-gut and voidedgut copepods yielded purple sulfur bacteria whereas anoxic incubations of fecal pellet-associated bacteria did not enrich for purple sulfur bacteria, suggesting that these bacteria are not food-associated. The growth of purple sulfur bacteria in these enrichments also paralleled increases in acetylene reduction, suggesting that these bacteria are active nitrogen fixers.

\section{MATERIALS AND METHODS}

Collection of copepods and anoxic, microbial enrichments from copepod-associated bacteria. Total plankton was collected during day tows with a $64 \mu \mathrm{m}$ mesh plankton net at $15 \mathrm{~m}$ depth at $18^{\circ} \mathrm{N}, 63^{\circ} \mathrm{W}$ and from a depth profile of $10-25,50,100$ and $200 \mathrm{~m}$ depth at $17^{\circ} 30^{\prime} \mathrm{N}, 63^{\circ} \mathrm{W}$ in the Eastern Caribbean Sea in January 1995 . The copepods were sorted from the plankton and transferred live into $0.45 \mu \mathrm{m}$ prefiltered seawater taken from the same depths as the plankton tows. Except for the integrated tows from 10 to $25 \mathrm{~m}$, only the copepods collected from a specific depth were pooled for the subsequent enrichments.

Although no effort was made to identify the copepods collected from the different depths, the major groups of zooplankton at this station were calanoid and cyclopoid copepods tentatively identified as being in the genera Nannocalanus, Neocalanus, Euchaeta, Undinula, Eucalanus and
Copilia (Owre \& Foyo 1967). The station selected for the plankton tows was in approximately $800 \mathrm{~m}$ of water and the depths sampled were chosen to correspond to depths above, within and below the chlorophyll maximum, located at approximately 90 to $100 \mathrm{~m}$ depth as determined by an in situ fluorometer (Fig. 1).

Three types of samples (full-gut copepods, voidedgut copepods and fecal pellets) were prepared from the sorted material as inocula for the microbial enrichments. The different sample types also allowed us to operationally define the microbial populations as transient or resident copepod-associated bacteria. In our experimental design, a transient microbial population associated with copepods is defined as bacteria associated with the food and, hence, with the fecal pellets. A resident microbial population associated with the copepods would be present in copepods even with emptied gut tracts. Typical copepod densities in both the full-gut and voided-gut preparations averaged approximately 300 copepods $/ 100 \mathrm{ml}$ of filtered seawater. Typical fecal pellet densities averaged approximately 2000 pellets $/ 100 \mathrm{ml}$ of filtered seawater.

In order to prepare voided-gut copepods as a source of bacteria for the microbial enrichments, a subsample of the live, sorted copepods collected at each depth was transferred to vessels with a $100 \mu \mathrm{m}$ nylon mesh insert and containing $0.45 \mu \mathrm{m}$ prefiltered seawater. The copepods were not fed and were allowed to defecate. Randomly selected copepods were periodically examined with a dissecting scope to determine whether the guts were emptied; at room temperature, the average length of time for copepods with apparent voided gut tracts was generally $10 \mathrm{~h}$. These live, voided-gut copepods were transferred to $0.45 \mu \mathrm{m}$ prefiltered seawater. The fecal pellets produced during the voiding step were collected on a $35 \mu$ m nylon sieve, quickly counted under a dissecting scope and transferred to $0.45 \mu \mathrm{m}$ prefiltered seawater.

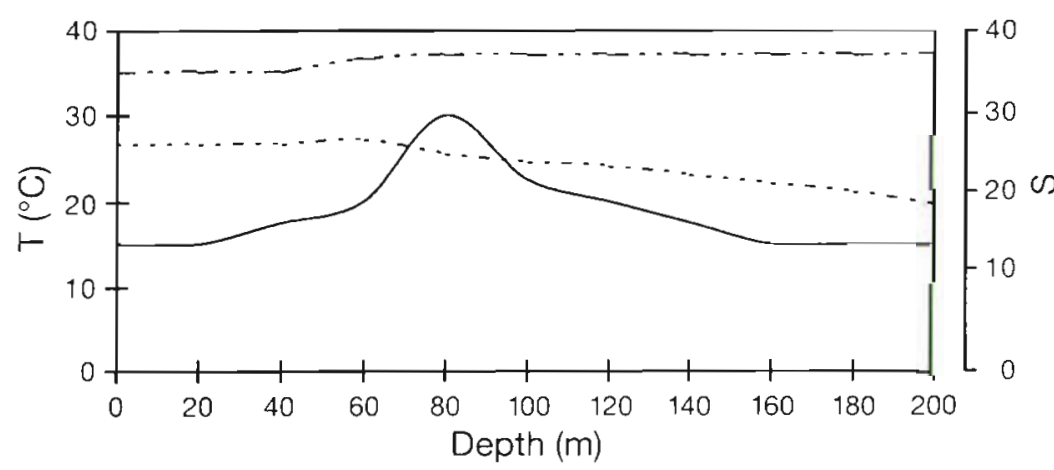

Fig. 1. Depth profile of temperature, salinity and in situ fluorescence to $200 \mathrm{~m}$ depth at $17^{\circ} 30^{\prime} \mathrm{N}, 63^{\circ} \mathrm{W}$ in the Caribbean Sea on January 12,1995 . (-- -) Temperature; (- - - ) salinity; (- $)$ fluorescence. Fluorescence is in relative units so no scale is presented. Note the chlorophyll maximum, based upon in situ fluorescence, at 90 to $100 \mathrm{~m}$ depth at this station 
Two sizes of containers, large volume (195 $\mathrm{ml})$ and small volume $(35 \mathrm{ml})$ bottles, were used for the microbial enrichment incubations. The large volume preparations held $160 \mathrm{ml}$ of a copepod or pellet suspension with a $35 \mathrm{ml}$ headspace while the small volume preparations held $20 \mathrm{ml}$ of a copepod or pellet suspension with a $15 \mathrm{ml}$ headspace. The bottles were made gastight by sealing the bottle with either a rubber stopper containing a septum insert and wiring the stopper onto the bottle with $20 \mathrm{G}$ wire or crimp-sealing an aluminum seal and butyl rubber septum to the serum bottle. The copepod and fecal pellet preparations were

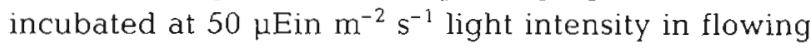
seawater baths maintained at Caribbean Sea surface seawater temperatures $\left(25\right.$ to $\left.28^{\circ} \mathrm{C}\right)$.

The full-gut copepod, voided-gut copepod and fecal pellet preparations were allowed to go anoxic. Resazurin, a redox indicator which is blue under positive redox potentials (i.e. oxic conditions), becomes pink at $-51 \mathrm{mV}$ and clears at $-110 \mathrm{mV}$ (i.e. anoxic conditions) (Levett 1991), was added at $0.1 \%$ final concentration to each of the preparations and each bottle was visually monitored for a change from oxic to anoxic conditions.

Based upon a color change in the resazurin indicator, the onset of anoxia occurred the fastest in the microbial enrichments of copepod-associated bacteria collected from the euphotic zone (Fig. 1). Even within the incubations of material from the euphotic zone, there was a clear distinction in the rate at which anoxia developed between the material collected at the deeper depths and the material collected at the shallower depths. For example, anoxia developed the fastest, within 12 to $16 \mathrm{~h}$, in the enrichments of copepod-associated bacteria from the chlorophyll maximum (100 m) and developed the slowest, after 36 to $48 \mathrm{~h}$ of incubation, in the enrichments of material from 10 to $25 \mathrm{~m}$. The onset of anoxic conditions in the microbial enrichments from the copepods collected below the euphotic zone $(200 \mathrm{~m})$ exhibited the longest lag and developed after $3 \mathrm{~d}$ of incubation.

Acetylene reduction assay of microbial enrichments. Nitrogen fixation rates in both the small volume and large volume preparations were monitored daily by the acetylene reduction assay (Capone 1993) using a Shimadzu mini-GC gas chromatograph equipped with a HayeSep-Q column and a flame ionization detector (FID). Acetylene gas was added at $15 \%$ of the headspace by syringe to each of the large volume and small volume copepod and fecal pellet preparations at the beginning of the experiments. Every $24 \mathrm{~h}$, the samples were vigorously shaken and duplicate gas samples of the headspace were collected and analysed for ethylene gas accumulation. The headspace samples were manually injected into the gas chromatograph and the ethylene concentration from each sample compared against daily analyses of a 100 ppm (Scotty Specialty Gases) ethylene standard. Additional control copepod samples were incubated without acetylene addition to monitor endogenous ethylene production.

Pigment analysis of purple sulfur bacterial enrichments from $100 \mathrm{~m}$ depth copepod preparations. Aliquots $(10 \mathrm{ml})$ of the enrichments from the $5 \mathrm{~d}$ old $100 \mathrm{~m}$ depth copepod incubations, which were dominated by the pigmented bacteria, were centrifuged and the pellets extracted with buffered, $90 \%$ methanol. The absorption spectrum of the extract was manually read on a Hitachi U-1100 spectrophotometer over a wavelength range of 400 to $925 \mathrm{~nm}$.

Upon return to Florida State University (FSU), the absorption spectrum of the extracts from the $100 \mathrm{~m}$ depth enrichments was compared with the published absorption spectra of a number of pigmented bacteria, including that of Chromatium purpuratum, a marine purple sulfur bacterium isolated from a sponge (Imhoff $\&$ Truper 1980). The absorption spectrum for C. purpuratum was taken from the whole cell spectrum of Imhoff \& Truper (1976) and corrected for spectral shifts of pigments in extracted form (Cohen-Bazire et al. 1957).

Transmission electron microscopy of purple sulfur bacterial enrichments from $100 \mathrm{~m}$ depth copepods. Upon return to FSU, $10 \mathrm{ml}$ aliquots of the $100 \mathrm{~m}$ depth copepod enrichments were fixed with $2.5 \%$ EM grade glutaraldehyde in $0.3 \mathrm{M}$ cacodylate buffer for $4 \mathrm{~h}$ at $4^{\circ} \mathrm{C}$, pelleted at $3000 \times g$ for 5 min, washed in cacodylate buffer and enrobed in agar (Gowing \& Wishner 1992). The agar block was dehydrated and infiltrated with Epon Araldite. Silver and gold sections were cut with a diamond knife and stained with $1 \%$ uranyl acetate and lead citrate. The stained sections were viewed and photographed in a JEOL $100 \mathrm{~B}$ electron microscope at $80 \mathrm{kV}$.

\section{RESULTS}

During a series of experiments designed to enrich for and cultivate anaerobic bacteria from copepod- and fecal pellet-associated bacteria, a bloom of purple/redpigmented bacteria unexpectedly appeared in anoxic, microbial enrichments from copepods collected in the Eastern Caribbean Sea (Fig. 2).

Growth of the pigmented bacteria in the enrichments occurred in depth sequence, with the $100 \mathrm{~m}$ depth enrichments exhibiting pigmented bacterial growth first, followed by the $50 \mathrm{~m}$ depth enrichments and then by the 10 to $25 \mathrm{~m}$ depth enrichments (Fig. 2). Growth of pigmented bacteria occurred the fastest within 12 to $18 \mathrm{~h}$, in the $100 \mathrm{~m}$ depth enrichments while growth of the pigmented bacteria in the enrichments 


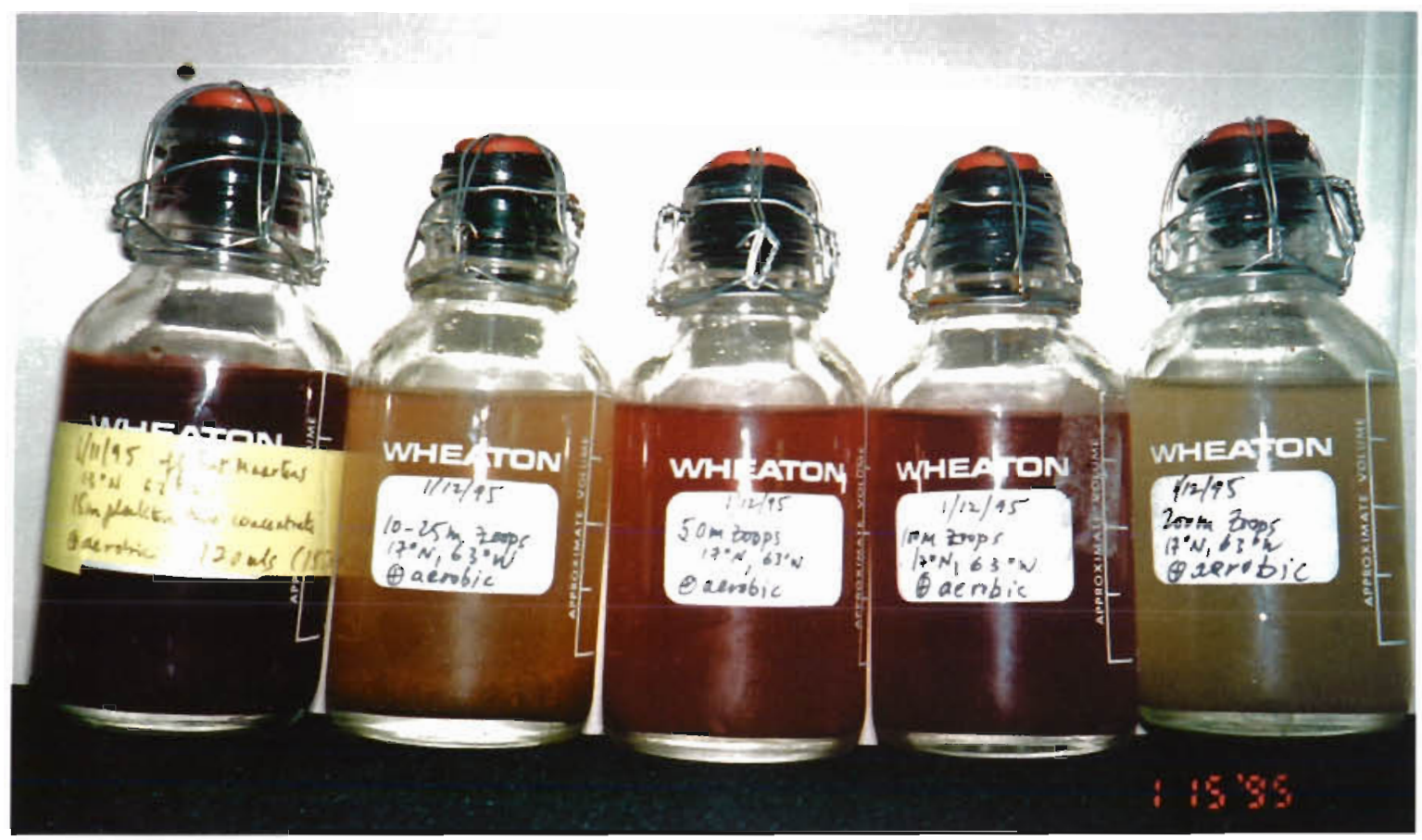

Fig. 2. Enrichments of purple sulfur bacteria in incubations of full gut copepods collected in the Caribbean Sea, January 1995. From left to right, the depths from which the copepods were collected include $15 \mathrm{~m}$ on January 11 at $18^{\circ} \mathrm{N}, 63^{\circ} \mathrm{W}$ and $10-25,50$, 100 and $200 \mathrm{~m}$ on January 12 at $17^{\circ} 30^{\prime} \mathrm{N}, 63^{\circ} \mathrm{W}$; photograph taken on January 15

of the samples from the shallowest depths developed only after $48 \mathrm{~h}$ of incubation. The enrichments from the copepods collected below the euphotic zone eventually showed growth of pigmented bacteria but only after approximately 8 to 9 mo of incubation.

When the pigmented bacteria appeared in the enrichments, the bacteria were further characterized by microscopy and pigment analysis. Purple sulfur bacteria can be distinguished from other bacteria in mixed populations because the intracellular sulfur globules give the cells a birefringent appearance under phase contrast microscopy (J. Meeks pers. comm. 1995, R. Castenholtz pers. comm. 1996). Light microscopy examination of the microbial enrichments revealed large, motile rods, approximately $1 \mu \mathrm{m}$ in diameter and 2 to $6 \mu \mathrm{m}$ in length, that dominated the enrichments from all euphotic zone depths after $5 \mathrm{~d}$ of incubation. By phase contrast illumination, the dominant cells possessed strongly refractile, intracellular inclusions. By epifluorescence light microscopy, the cells autofluoresced orange-yellow under blue light excitation and the cells were strongly phototactic to both UV and blue light excitation. Interestingly, the autofluorescence and phototactic behavior were lost in the isolates later cultivated from this material (M. Berry pers. comm.). The corkscrew-like movement of the cells indicated the cells had polar flagella. Upon return to FSU, transmission electron microscopy of the cells from the $100 \mathrm{~m}$ depth enrichments confirmed the dominant cells possessed intracellular sulfur globules (Fig. 3a) and photosynthetic vesicles (Fig. $3 \mathrm{~b}$ ), both traits characteristic of purple sulfur bacteria.

Onboard analysis of the methanol extracts from the $5 \mathrm{~d}$ old, $100 \mathrm{~m}$ depth microbial enrichments indicated the presence of 3 absorption maxima (Fig. 4) which were compared to the absorption spectra of several groups of pigmented bacteria. The absorption spectra exhibited a relatively narrow, major peak at $770 \mathrm{~nm}$ with a smaller, minor peak at $590 \mathrm{~nm}$, indicating the presence of bacteriochlorophyll a (Pfennig \& Truper 1994). A broad maximum over 425 to $550 \mathrm{~nm}$ in the absorption spectra indicated the presence of carotenoids. The carotenoid spectra compared most closely to carotenoids in the okenone series, a major group of carotenoids common to purple sulfur bacteria (Pfennig \& Truper 1994).

Acetylene reduction was monitored daily in these enrichments. Increases in acetylene reduction coincided with growth of the pigmented bacteria in each enrichment. For example, after an initial lag period of approximately $24 \mathrm{~h}$, acetylene reduction increased at an exponential rate in the enrichments of the $100 \mathrm{~m}$ depth material over the $5 \mathrm{~d}$ of the experiment (Fig. 5). Bacterial densities, monitored by DAPI direct counts, increased from an average of $8 \times 10^{6}$ cells $\mathrm{ml}^{-1}$ at the beginning of the incubations to $1-5 \times 10^{9} \mathrm{cells}^{-1}$ after $5 \mathrm{~d}$ of incubation (Fig. 5). Based upon the pres- 


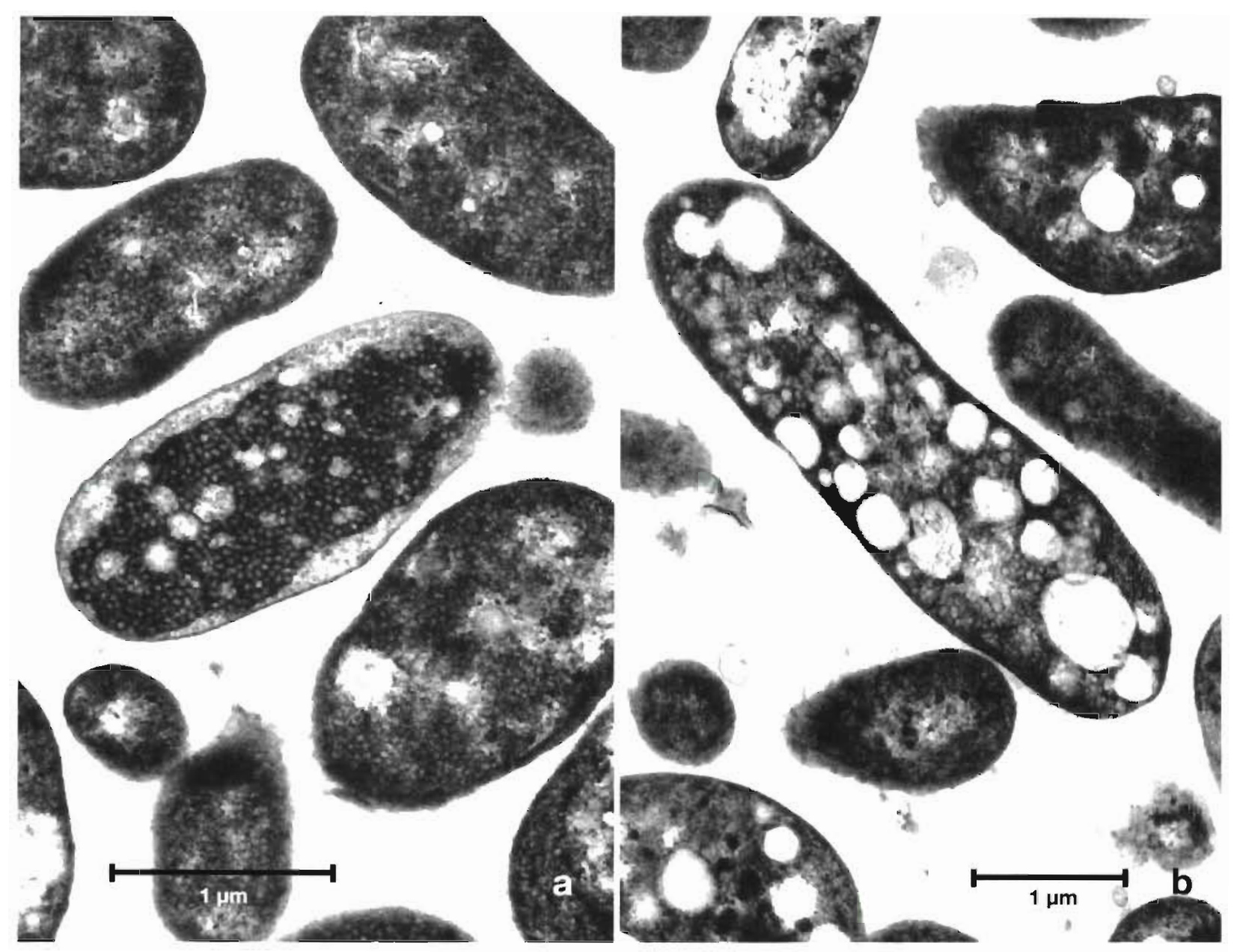

Fig. 3. Transmission electron micrographs (TEM) of the purple sulfur bacteria which dominated the Caribbean Sea $100 \mathrm{~m}$ depth copepod enrichments. (a) Sulfur globules appear as electron-transparent, intracellular inclusions by TEM. (b) Photosynthetic membranes, in the form of $40 \mathrm{~nm}$ vesicles, fill the cell. Flagella were lost in the sample preparation. Total magnification is $45000 \times$

ence of birefringent, motile cells in the enrichments, pigmented bacteria dominated the enrichments after $3 \mathrm{~d}$. The pigmented bacteria represented 80 to $85 \%$ of the total bacterial population in the $100 \mathrm{~m}$ depth enrichments after $5 \mathrm{~d}$ of incubation (Fig. 5).
Three different types of preparations using copepods as the source material - full gut copepods, voided gut copepods and copepod fecal pellets - were incubated under the same light and temperature conditions in order to determine which sample type was the pre-
Fig. 4. Pigment analysis of the purple sulfur bacteria which dominated the enrichments from Caribbean Sea copepods collected at $100 \mathrm{~m}$ depth. (-) Absorption spectrum for pigments extracted from the purple sulfur bacteria in the $100 \mathrm{~m}$ depth enrichments; (...) absorption spectrum for Chromatium purpuratum (Imhoff \& Truper 1976). The major absorption peak at $770 \mathrm{~nm}$ and the minor peak at $590 \mathrm{~nm}$ indicate the presence of bacteriochlorophyll $a$ while the broad absorption maximum from 425 to $550 \mathrm{~nm}$ indicates the presence of okenone, a carotenoid accessory pigment

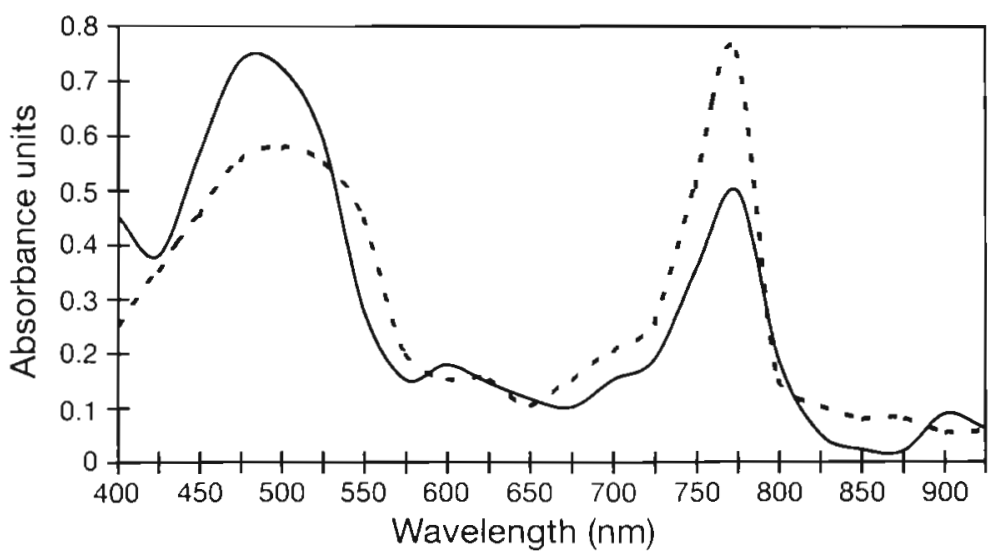




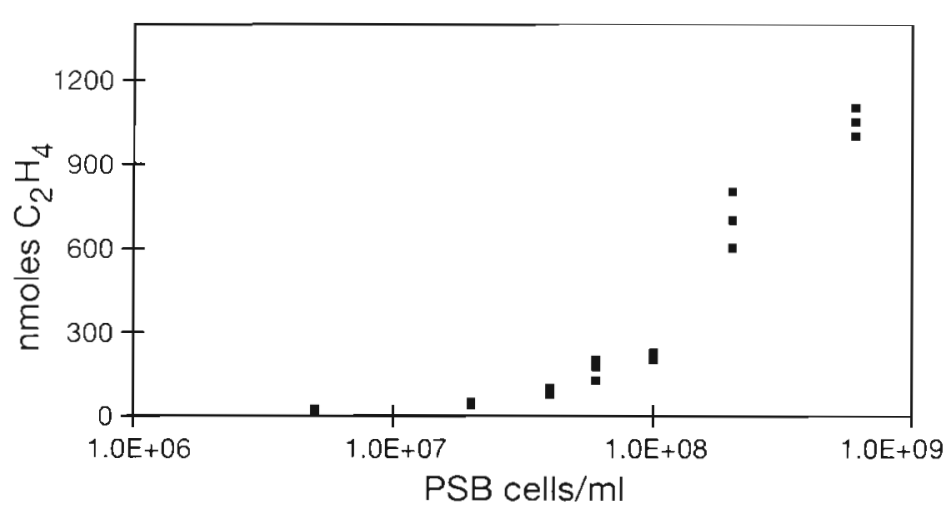

Fig. 5. Increases in acetylene reduction and growth of purple sulfur bacteria (PSB) in Caribbean Sea copepod enrichments. Ethylene production was monitored daily by GC/FID and calculated as total nanomoles of ethylene produced per $\mathrm{ml}_{\text {; }}$ total bacterial abundances were monitored daily by DAPI direct counts while purple sulfur bacteria was followed by counting cells with intracellular sulfur globules. At the beginning of the incubations, there were no bacteria with apparent intracellular sulfur globules

dominant habitat for the pigmented bacteria. Only the full-gut and voided-gut copepod microbial enrichments became anoxic with subsequent ethylene gas production and the development of the pigmented bacterial bloom (Table 1). The fecal pellet microbial enrichments developed mildly anoxic conditions and turbid bacterial growth. However, there was no growth of pigmented bacteria or ethylene production in the fecal pellet microbial enrichments (Table 1).

\section{DISCUSSION}

Purple sulfur bacteria appear to be specifically associated with planktonic copepods. Several aspects of our study support this observation. These experiments were conducted with pelagic copepods collected in an $800 \mathrm{~m}$ deep water column in the Caribbean Sea, at a station far from microbial mats, marine sediments or other benthic sites which could have served as inocula for these enrichments. This experimental plan is important in the interpretation of the results of this study. Other studies have noted that zooplankton and protozoa are able to swim into anoxic layers of lakes and consume purple sulfur and green sulfur bacteria (Fenchel 1969, Gophen 1977). In our study, we minimized the possibility that the purple sulfur bacteria are foodassociated because the station was a deep water site.

The plankton tow was carefully sorted in such a fashion so that the bacteria which developed in the subsequent microbial enrichments originated from the copepods and not from unidentifiable material in the tow. Other workers have isolated anaerobes, such as methanogens, from plankton enrichments (Cynar \& Yayanos 1991) but little effort was made to classify or sort the material, making it difficult to conclude whether the methanogens isolated from these samples were enriched from phytoplankton, zooplankton or detritus.

Fecal pellets were prepared and incubated in the same manner as the copepods in order to isolate the microenvironment where the purple sulfur bacteria might be found. None of the fecal pellet preparations yielded purple sulfur bacteria, even after continued incubation of the material under similar light and temperature conditions after return to FSU. Furthermore, the voided-gut copepod material yielded enrichments of purple sulfur bacteria. This suggests that the purple sulfur bacteria are not voided from the gut but somehow remain associated with the copepod.

Bacteria are commonly found within fecal pellets (Gowing \& Silver 1983, Nagasawa 1987, 1992, Gowing \& Wishner 1992). We found that many types of anaerobic bacteria, such as sulfate-reducing bacteria, methanogens and fermentative bacteria as well as the purple sulfur bacteria, are members of both copepod and fecal pellet bacterial populations (Proctor unpubl.). However, under the conditions of sample preparation and incubation described in this study, purple sulfur bacteria do not appear to be members of the fecal pellet bacterial populations.

Table 1. Redox potential, acetylene reduction and presence of purple sulfur bacteria in incubations of copepods and their fecal pellets. Redox potential for each incubation is indicated by the oxidized or reduced resazurin; degree of acetylene reduction is based upon the relative amount of ethylene production after $5 \mathrm{~d}$ of incubation; and the presence of purple sulfur bacteria is based upon microscopic observation of the enrichments after $5 \mathrm{~d}$ of incubation. The relative abundance of purple sulfur bacteria in the enrichments is indicated as the percentage of purple sulfur bacteria to the total number of bacteria

\begin{tabular}{|lccc|}
\hline Inoculum source & Reducing conditions & Acetylene reduction & $\begin{array}{c}\text { Percentage of purple sulfur bacteria } \\
\text { to total bacteria (\%) }\end{array}$ \\
\hline Full-gut copepods & Reduced & +++ & $80-85$ \\
Voided-gut copepods & Reduced & ++ & $40-50$ \\
Fecal pellets & Mildly reduced & - & - \\
\hline
\end{tabular}


Although the fecal pellet enrichments became anoxic, purple sulfur bacteria never developed in the enrichments. This is somewhat surprising since purple sulfur bacteria have some oxygen tolerance (Kampf \& Pfennig 1980, Overmann \& Pfennig 1992) and can carry out chemotrophic growth, which consumes oxygen until conditions permit bacteriochlorophyll synthesis (Kampf \& Pfennig 1980). In addition, some purple sulfur bacteria are capable of heterotrophy (Kampf \& Pfennig 1980). No effort was made to amend the fecal pellet, full-gut and voided-gut copepod preparations with either sulfide (chemotrophic growth) or organic carbon (heterotrophic growth) to equalize the sulfur or carbon content among the 3 preparations. However, at thousands of pellets per $100 \mathrm{ml}$ of seawater, fecal pellet densities in the enrichments were equivalent to the gut carbon content of hundreds of copepods. In fact, the fecal pellet densities were sufficiently high for anoxic conditions to develop within $3 \mathrm{~d}$, suggesting that the organic carbon content was similar in the full-gut, voided-gut and fecal pellet preparations. Collectively, these results support the argument that the purple sulfur bacteria appear to be specifically associated with the copepods.

The $100 \mathrm{~m}$ depth enrichments of copepods developed blooms of purple sulfur bacteria well before the enrichments from the other depths. If the purple sulfur bacteria were incidentally associated with the copepods, then one would not expect a sequential growth of these photosynthetic anaerobes and any of the samples might have resulted in blooms of purple sulfur bacteria or purple sulfur bacteria might have appeared after long and variable lag periods. Furthermore, the purple sulfur bacteria began to develop in less than $1 \mathrm{~d}$ in the $100 \mathrm{~m}$ depth samples, suggesting that the inoculum size was large, i.e. these photosynthetic anaerobes were abundant members of the copepodassociated bacteria.

We estimated the growth rates of the purple sulfur bacteria in our enrichments, based upon the final densities of purple sulfur bacteria in the enrichments after $3 \mathrm{~d}$ of incubation and the direct count estimates of bacterial abundances of $10^{4}$ to $10^{6}$ bacteria copepod ${ }^{-1}$ (Nagasawa 1987, Delille \& Razouls 1994, Proctor \& Kelley unpubl.). Our estimates suggest that these photosynthetic anaerobes had on the order of 4 to $8 \mathrm{~h}$ generation times under the incubation conditions of this study. These estimates do not take into account any losses of the bacteria and assume that all of the bacteria are purple sulfur bacteria, therefore, these may represent underestimates. Although these fast growth rates may not be typical, these growth rates have been seen in cultures of purple sulfur bacteria (van Gemerden 1980), suggesting that our estimates are reasonable.
We found that photosynthetic anaerobes were associated with copepods even with emptied gut tracts. Copepods have epizooic flora (Sochard et al. 1979, Nagasawa et al. 1985, Nagasawa 1992) and we cannot currently eliminate the possibility that purple sulfur bacteria are on the copepod exoskeleton. However, several reasons suggest that it is highly unlikely these bacteria are members of the epizooic flora. Bacteria on the exoskeleton are constantly in contact with oxygen so anaerobes such as the purple sulfur bacteria, which perform anoxygenic photosynthesis, would not be able to do so attached to the exoskeleton. In addition, copepods absorb oxygen through their exoskeleton, indicating that oxygen-sensitive bacteria, like the purple sulfur bacteria, are unlikely to be located on the exoskeleton. Although carbon dioxide would be available in the surrounding seawater as well as from the respiring copepod, the electron donors for anoxygenic photosynthesis, such as sulfide and fatty acids, are not likely to be available at significant concentrations in aerobic environments, further arguing for the absence of purple sulfur bacteria on the exoskeleton.

As noted earlier, some purple sulfur bacteria can grow chemotrophically or even heterotrophically under microaerophilic conditions (Kampf \& Pfennig 1980, Overmann \& Pfennig 1992), raising the possibility that these bacteria may exist as chemotrophs or heterotrophs on the copepod exoskeleton. However, in continuous culture studies of several species of purple sulfur bacteria, Overmann \& Pfennig (1992) found that a minimum of $5 \mathrm{~d}$ was needed for a transition from phototrophic to chemotrophic growth. In our enrichment studies, the purple sulfur bacteria developed very rapidly, in less than $3 \mathrm{~d}$, indicating that there was no lag period needed to induce bacteriochlorophyll synthesis. This suggests that the bacteria in our enrichments were more likely carrying out a photosynthetic mode of metabolism rather than a chemotrophic or heterotrophic mode of metabolism.

For a number of reasons, our experiments suggest that the purple sulfur bacteria are members of the gut flora in copepods. Purple sulfur bacteria require oxygen-free conditions to carry out photosynthesis since bacteriochlorophyll synthesis occurs only under anoxic conditions. The bacterial requirement for sulfide or reduced carbon compounds as electron donors for photosynthesis further limits the microenvironments these bacteria are likely to inhabit. Both of the requirements for photosynthesis could be met in the gut tracts of copepods. Furthermore, copepods are transparent to light, making zooplankton ideal habitats for photosynthetic anaerobes.

The presence of purple sulfur bacteria specifically associated with zooplankton has several important implications for microbial diversity as well as for carbon and nitrogen flux in the sea. Since anaerobes are 
not found as sole inhabitants of an environment but as syntrophic members of complex consortia, the presence of in situ methane and sulfide production in the ocean actually points to the presence of anaerobic consortia in the ocean. The results of this study further suggest that the distribution of these anaerobic consortia in the ocean may be equally complex, with some anaerobes found associated with detritus such as fecal pellets while other anaerobes may be found specifically associated with the living plankton (Proctor unpubl.).

Prior to the discovery of these purple sulfur bacteria in the open ocean, few nitrogen-fixing microorganisms have been identified in the sea, other than the colonial cyanobacterium Trichodesmium (Carpenter 1983) and the diatom/cyanobacterial symbioses of Rhizosolenia (Villareal 1990) and Hemiaulus (Villareal 1994). The potential for nitrogen fixation by purple sulfur bacteria represents a new and previously undescribed source of 'new' nitrogen to the oceans' food web (Legendre \& Gosselin 1989). Recently, some studies have demonstrated that primary production occurs in the absence of measureable nutrients in the oligotrophic oceans (Michaels et al. 1994), further supporting the idea that microorganisms with the capacity to supply their own nutrients, such as these nitrogen-fixing, photosynthetic bacteria, are active in the ocean. Furthermore, the results of this study indicate that there are nitrogenfixing microorganisms in the ocean which are present, not as members of the bacterioplankton, but as inhabitants of little-studied microenvironments such as the gut tracts of zooplankton.

The discovery of purple sulfur bacteria in association with copepods suggests that we still know little about the microbiology of the sea. The recent use of molecular approaches has demonstrated that many microorganisms in the ocean have yet to be cultivated (Schmidt et al. 1991, Fuhrman et al. 1993, Mullins et al. 1995). Yet culturability may not be the only limiting factor in understanding the microbial diversity of the sea. The results of this study show that there are newly discovered microorganisms that are cultivable but that are found in microenvironments, such as zooplankton guts, that have received relatively little attention.

Acknowledgements. I thank Dr J. P. Zehr, Rensselaer Polytechnic Institute, for the opportunity to join his cruise and for his continued interest in the zooplankton gut flora work; Dr J. Meeks, U. C. Davis, for insightful discussions and for the onboard spectrophotometric analysis of the bacterial pigments; Mr J. Burns, Univ. Maryland, for assistance with the onboard acetylene reduction assays; $\mathrm{Ms}$ E. Hughes and $\mathrm{Mr} M$. Berry, Florida State University (FSU), for initial characterization of the purple sulfur bacterial strains and Captain $W$. Schwartz and the crew of the RV 'Seward-Johnson' of the Harbor Branch Oceanographic Institute. This research was supported by FSU and by an NSF research planning grant.

\section{LITERATURE CITED}

Bianchi M, Marty D, Teyssie JL, Fowler SW (1992) Strictly aerobic and anaerobic bacteria associated with sinking particulate matter and zooplankton fecal pellets. Maı Ecol Prog Ser 88:55-60

Capone DG (1993) Determination of nitrogenase activity in aquatic samples using the acetylene reduction procedure. In: Kemp PF, Sherr BF, Sherr EB, Cole JJ (eds) Handbook of methods in aquatic microbial ecology. Lewis Press, Boca Raton, p 621-631

Carpenter EJ (1983) Nitrogen fixation by marine Oscillatoria (Trichodesmium) in the world's oceans. In: Carpenter EJ, Capone DG (eds) Nitrogen in the marine environment. Academic Press, New York, p 65-103

Cohen-Bazire G, Sistrom WR, Stanier RY (1957) Kinetic studies of pigment synthesis by purple non-sulfur bacteria. J Cell Comp Physiol 49:25-68

Cutter GA, Krahforst CF (1988) Sulfide in surface waters of the western Atlantic Ocean. Geophys Res Lett 15: $1393-1396$

Cynar FJ, Yayanos AA (1991) Enrichment and characterization of a methanogenic bacterium from the oxic upper layer of the ocean. Curr Microbiol 23:89-96

de Angelis M, Lee C (1994) Methane production during zooplankton grazing on marine phytoplankton. Limnol Oceanogr 39:1298-1308

Delille D, Razouls S (1994) Community structures of heterotrophic bacteria of copepod fecal pellets. J Plankton Res 16:603-615

Fenchel T (1969) The ecology of marine microbenthos. IV. Structure and function of the benthic ecosystem, its chemical and physical factors and the microfauna communities with special reference to the ciliated protozoa. Ophelia 6:1-182

Fowler VJ, Pfennig N, Schubert W, Stackebrandt E (1984) Towards a phylogeny of phototrophic purple sulfur bacteria: $16 \mathrm{~S}$ rRNA oligonucleotide cataloguing of 11 species of Chromatiaceae. Arch Microb 139:382-387

Fuhrman JA, McCallum K, Davis AA (1993) Phylogenetic diversity of subsurface marine microbial cornmunities from the Atlantic and Pacific Oceans. Appl Environ Microb 59:1294-1302

Gophen M (1977) Feeding of Daphnia on Chlamydomonas and Chlorobium. Nature 265:271-273

Gowing MM, Silver MW (1983) Origins and microenvironments of bacteria mediating fecal pellet decomposition in the sea. Mar Biol 73:7-16

Gowing MM, Wishner KF (1992) Feeding ecology of benthopelagic zooplankton on an eastern tropical Pacific seamount. Mar Biol 112:451-467

Guerrero R, Montesinos E, Pedros-Alio C, Esteve I, Mas J, Gemerden HV, Hofman PAG, Bakker JF (1985) Phototrophic bacteria in two Spanish lakes. I. Vertical distribution and limiting factors. Limnol Oceanogr 30: 919-930

Hansen B, Bech G (1996) Bacteria associated with a marine planktonic copepod in culture. I. Bacterial genera in seawater, body surface, intestines and fecal pellets and succession during fecal pellet degradation. J Plankton Res 18 $257-273$

Imhoff J (1992) Taxonomy, phylogeny and general ecology of anoxygenic phototrophic bacteria. In: Mann NH, Carr NG (eds) Photosynthetic prokaryotes. Plenum, New York, p 53-92

Imhoff JF, Truper HG (1976) Marine sponges as habitats of anaerobic phototrophic bacteria. Microb Ecol 3:1-9 
Imhoff JF, Truper HG (1980) Chromatium purpuratum, sp. nov., a new species of the Chromatiaceae. Zbl Bakt 1 Orig C $1: 61-69$

Jørgensen BB, Fenchel T (1974) The sulfur cycle of a marine sediment model system. Mar Biol 24:189-201

Kampf C, Pfennig N (1980) Capacity of Chromatiaceae for chemotrophic growth. Specific respiration rates of Thiocystis violacea and Chromatium vinosum. Arch Microbiol $127: 125-135$

Legendre L, Gosselin M (1989) New production and export of organic matter to the deep ocean: consequences of some recent discoveries. Limnol Oceanogr 34:1374-1380

Levett PN (1991) Anaerobic microbiology. IRL Press, Oxford

Longhurst AR (1985) Relationship between diversity and the vertical structure of the upper ocean. Deep Sea Res 32: $1535-1570$

Longhurst AR, Herman AW (1981) Do oceanic zooplankton aggregate at or near the deep chlorophyll maximum? J Mar Res 39:353-356

Michaels AF, Bates NR, Buessler KO, Carlson CA, Knap AH (1994) Carbon-cycle imbalances in the Sargasso Sea. Nature 372:537-540

Mullins TD, Britschgi TB, Krest RL, Giovannoni SJ (1995) Genetic comparisons reveal the same unknown bacterial lineages in Atlantic and Pacific bacterioplankton communities. Limnol Oceanogr 40:148-158

Nagasawa $S$ (1987) Exoskeletal scars caused by bacterial attachment to copepods. J Plankton Res 9:749-753

Nagasawa S (1992) Concurrent observations on gut interior and fecal pellets of marine crustaceans. J Plankton Res 14 : $1625-1630$

Nagasawa $S$, Nemoto T (1988) Presence of bacteria in guts of marine crustaceans and on their fecal pellets. J Plankton Res 10:559-564

Nagasawa S, Simidu U, Nemoto T (1985) Scanning electron microscopy investigation of bacterial colonization of the marine copepod Acartia clausi. Mar Biol 87:61-66

Oremland RS (1979) Methanogenic activity in plankton sam-

Responsible Subject Editor: T. Fenchel, Helsingør, Denmark ples and fish intestines: a mechanism for in situ methanogenesis in oceanic surface waters. Limnol Oceanogr 24 : $1136-1141$

Overmann J, Pfennig N (1992) Continuous chemotrophic growth and respiration of Chromatiaceae species at low oxygen concentrations. Arch Microbiol 158:59-67

Owre HB, Foyo M (1967) Copepods of the Florida Current. Inst of Mar Sci, University of Miami, Miami

Paterek JR, Paynter JB (1988) Populations of anaerobic phototrophic bacteria in a Spartina alterniflora salt marsh. Appl Environ Microbiol 54:1360-1364

Pfennig N (1978) General physiology and ecology of photosynthetic bacteria. In: Clayton RE, Sistrom WR (eds) The photosynthetic bacteria. Plenum Press, New York, p 3-18

Pfennig $N$, Truper HG (1994) Anoxygenic phototrophic bacteria, Vol 3. In: Holt JG, Krieg NR, Sneath PHA, Staley JT, Williams ST (eds) Bergey's manual of systematic bacteriology. Williams and Wilkins, New York, p 353-376

Schmidt TM, DeLong EF, Pace NR (1991) Analysis of a marine picoplankton community by $16 \mathrm{~S}$ rRNA gene cloning and sequencing. J Bacteriol 173:4371-4378

Shanks AL, Reeder ML (1993) Reducing microzones and sulfide production in marine snow. Mar Ecol Prog Ser 96: $43-47$

Sochard MR, Wilson DF, Austin B, Colwell RR (1979) Bacteria associated with the surface and gut of marine copepods. Appl Environ Microbiol 37:750-759

Star J, Mullin M (1981) Zooplanktonic assemblages in three areas of the North Pacific as revealed by continuous horizontal transects. Deep Sea Res 28:1302-1322

van Gemerden $H$ (1980) Survival of Chromatium vinosum at low light intensities. Arch Microb 125:115-121

Villareal TA (1990) Laboratory cultivation and preliminary characterization of the Rhizosolenia-Richelia symbiosis. PSNZ I: Mar Ecol 11:117-132

Villareal TA (1994) Widespread occurrence of the Hemiauluscyanobacterial symbiosis in the southwest North Atlantic Ocean. Bull Mar Sci 54:1-7

Manuscript first received: August 8, 1996

Revised version accepted: December 17, 1996 